\title{
Managerial Performance of Fast-Food Restaurant Managers in the Philippines: Basis for Capability Enhancement Program
}

\author{
Jessie Anne T. Demetillo, Ph.D ${ }^{\text {., Liane Vina G. Ocampo, Ph.D. }{ }^{\text {, }} \text {, Rosario B. Gumban, Ph.D. }}$ \\ ${ }^{a}$ Cavite State University, Philippines, \\ ${ }^{\mathrm{b}}$ Cavite State University, Philippines, \\ ${ }^{\mathrm{c}}$ Cavite State University, Philippines \\ jtdemetillo@cvsu.edu.ph, ${ }^{\mathrm{b}}$ lianeocampo@cvsu.edu.ph, ${ }^{\mathrm{c}}$ rbgumban@cvsu.edu.ph
}

Article History: Received: 10 November 2020; Revised 12 January 2021 Accepted: 27 January 2021; Published online: 5 April 2021

\begin{abstract}
The study generally assessed the management skills, work values, and job performance of the fast-food restaurant managers in the Philippines as a basis for developing managerial capability enhancement program. Specifically, it aims to determine the profile; the level of the management skills, work values, and job performance as assessed by the managers and of their staff; and the relationship that exists among the variables: profile and management skills, profile and work values, profile and job performance, management skills and job performance, and work values and job performance. The results revealed that most managers ages 25 and below and with bachelor's degree; they mostly served as a manager for only five years and below; had attended five and below the number of trainings relative to their position; and have an average monthly income of P15,000 and below. Managers are excellent in management skills, work values, and job performance as assessed by themselves and their staff. Results also showed that the average monthly income was found to have a significant relationship with management skills, work values, and job performance. Further, management skills and work values are highly significant to the fast-food restaurant managers' job performance.
\end{abstract}

Keywords: Job Performance, Management Skills, Managers, Work Values

\section{Background, Motivation, and Objectives}

Fast-food restaurant is a particular type of restaurant characterized by its fast-food cuisine and minimal table service (allfoodbusiness, 2012). The industry term for the fast-food establishment is Quick-Service Restaurant or QSR (Celentano, 2019). The quick-service restaurant industry is a significant and growing aspect of the overall restaurant industry (Mason, Jones, Benefield \& Walton, 2016). Just like in other countries, this restaurant industry had flourished very well in the Philippines. Filipinos love to eat, which is why lots of restaurants and fast-food restaurants, are scattered in the cities (Campuscrosswalk.org, n.d.). In recent years, more and more fast-food restaurants are sprouting and grabbing shares in the market, particularly in the city of TreceMartires. There are currently seven out of 10 present in the city listed in the ten best and most popular Philippine fastfoods. According to Bermosa (2015), the ten best and most popular Philippine fast foods are Jollibee, McDonald's, Chowking, Greenwich, Pizzahut, MangInasal, Kentucky Fried Chicken (KFC), Max's Fried Chicken, Tokyo-Tokyo, and Kenny Rogers. These fast-food restaurants compete not only in delivering excellent and preeminent products and services to the customers they serve but also in retaining and attracting more and more customers.

Today, managing a fast-food restaurant is not as easy as it is. It is a difficult task, signifying huge responsibilities (Milicevic, n.d.) and challenges for every manager. Campbell (2017) specified that managing a restaurant is like watching over a complicated machine's gears. Confined with the typical managerial concerns of employees and customers and dealing with food service and the unique baggage that comes. Consequently, the restaurant industry's overall success lies in the sound and outstanding management of the restaurant managers (Cagurangan, 2017). Whereas poor management skills carry long-term effects that might infect the entire organization (Lavoie, 2016). As such, it is imperative to the management to ensure that they have the managers that possess exemplary management skills, work values, and job performance and that an assessment should be regularly done as a basis for continuous improvement.

Management skills are what the manager uses to assist the organization in accomplishing its goals. Specifically, a manager will use his or her abilities, knowledge base, experiences, and perspectives to increase the productivity of those with whom they manage (Hartzell, 2019).On the other hand, strong work ethics and values play an essential role in the workplace (Reddy, 2016). Further, Lin, Shen, and Hsu (2015) asserted that understanding employees' work values had become a key concern or issue for organizations that aim to achieve higher performances. 
Workplace values are the guiding principles that are most important to an individual the way they work, and they can use these deeply held principles to choose between right and wrong ways of working (Mindtools, n.d.). Along this line, a company's success is directly affected by the performance of the employees within the organization. Businesses that clearly understand the impact of their employees' performance can better manage employee output and productivity. Subsequently, proper management of employee performance helps any business to increase profits (Rodriguez, 2017).

This study was conducted to assess the level of management skills, work values, and job performance of the fastfood restaurant managers in TreceMartires City, Cavite, Philippines, as a basis for designing a managerial capability enhancement program for continuous improvement.

\section{Statement of contribution and methods}

In a fast-growing organization, an assessment of the management skills, work values, and job performance of the restaurant managers overtime is highly essential for designing capability enhancement programs for continuous improvement. Top management and the human resources management department, must assess their employees' performance periodically to ensure that they deliver an exceptional contribution to the organization. This research undertaking corroborates the relationship of profile variables considered in the study to the management skills, work values, and job performance of the fast-food restaurant managers. The study likewise validates the relationship between management skills and work values to the fast restaurant managers' job performance. This study will be beneficial for strategic decision-making of the top management and human resources department of the fastfood restaurants in designing the managerial capacity enhancement programs for the continuous improvement of the fastfood restaurant managers.

The study will further divulge valuable information to business enthusiasts who plan to engage in a fast-food restaurant business. Additionally, the results generated can also be used as a reference and supplement for more extensive research related to the topic.

This study's research design was a descriptive-research method, which includes the data gathering using survey questionnaires and analysis of the results using statistical tools.

All managers and staff of the quick service restaurants in TreceMartires City, Cavite, Philippines that belong to the ten best and most popular in the Philippines, as cited by Bermosa (2015) and who voluntarily responded to the request, were considered respondents of the study. An approval from the management of each fast-food restaurants were first sought, and when permissions were granted, surveys were subsequently conducted.

Survey questionnaires used were designed for the fast-food restaurant managers and staff to answer.

Part I of the questionnaire covers the gathering of information about the managers' profile in terms of age, educational attainment, number of years in service, number of training attended, and average monthly income.

Part II of the questionnaire was designed to gather information about management skills on how managers and staffs view it among fast-food restaurants. These were assessed based on the ten skills that manager needs to master to stay on top of their performance and become an effective leader by Smuin (2017).

On the other hand, Part III was constructed to gather information about the level of work values on how the managers and staff respondents view it among fast-food restaurants. These were assessed based on the top ten work values that the employers look for their employees and are good indicators for success by Loretto (2018).

Lastly, part IV covers to gather information about the job performance on how it is viewed by the managers and staff participants among fast-food restaurants. The instrument used in this part was patterned on the SPSU Job Performance Evaluation Form (pdffiller.com, n.d.).

A pilot survey was carried out from randomly selected participants to ensure the instrument's validity and reliability. Content validity was determined by the managers and staff of the fast-food restaurants not included in the study. Their comments were considered in the preparation of the instrument's final copy.

Statistical tools such as frequency count and percentage were utilized to describe the fast-food restaurant managers' profile. At the same time, mean was used to summarize, describe and analyze the data on the level of management skills, work values, and job performance as assessed by the managers themselves and their staff. Moreover, the Spearman's Rank Correlation Coefficient was employed to investigate the relationship of profile and management skills, profile and work values, and profile and job performance. Lastly, Pearson's $r$ was used to determine the relationship between management skills and job performance, and work values and job performance. 


\section{Results, discussions and conclusions}

\section{Profile of the Fast Food Restaurant Managers in Cavite}

Table I. Frequency and percentage distribution on the profile of managers according to age

\begin{tabular}{|l|l|l|}
\hline Age & $\begin{array}{l}\text { Frequency } \\
(\mathbf{n = 3 5})\end{array}$ & Percentage (\%) \\
\hline 25 and below & 20 & 57.14 \\
\hline $26-35$ & 10 & 28.57 \\
\hline $36-45$ & 4 & 11.43 \\
\hline $46-55$ & 1 & 2.86 \\
\hline
\end{tabular}

Age. Of the 35 participants, $20(57.14 \%)$ are 25 years old and below, hence are categorized as young (Table I). This findings support the fact that most fast-food restaurants encouraged fresh graduate applicants with experience as a service crew to apply as a manager. They are usually young and seemingly be classified as with less experience. Many agree that people benefit from the increased experience of age (kingworldnews.com, n.d.). According to Wildes (2008), age factor was significant in the foodservice industry.

Table II. Frequency and percentage distribution on the profileof managers according to educational attainment

\begin{tabular}{|l|l|l|}
\hline $\begin{array}{l}\text { Educational } \\
\text { Attainment }\end{array}$ & $\begin{array}{l}\text { Frequency } \\
(\mathbf{n = 3 5})\end{array}$ & $\begin{array}{l}\text { Percentage } \\
(\mathbf{\%})\end{array}$ \\
\hline Bachelor's Degree & 33 & 94.29 \\
\hline Master's Degree & 1 & 2.86 \\
\hline With Ph.D./D Units & 1 & 2.86 \\
\hline
\end{tabular}

Educational attainment. The result shows that the majority or $33(94.29 \%)$ of the fast-food restaurant managers have only a bachelor's degree (Table II).

The key to success in the restaurant industry is education (Milicevic, n.d). Moreover, Simon (2019) affirmed that leadership and management courses are essential for imparting practical skills to manage teams effectively. These are ideal for current managers who want to improve their skills and desiring or new managers to enhance their managerial skills. While various restaurant managers have on the job training, a post-secondary degree or college coursework is becoming a preference of employers (study.com, n.d.).

These infer that exposure to a higher level of education and professional development means having better management skills and work values, vital for effective and efficient job performance.

Table III. Frequency and percentage distribution on the profile of managers according to number of years in service as a manager

\begin{tabular}{|l|l|l|}
\hline $\begin{array}{l}\text { Number of years } \\
\text { in service }\end{array}$ & $\begin{array}{l}\text { Frequency } \\
(\mathbf{n = 3 5})\end{array}$ & $\begin{array}{l}\text { Percentage } \\
(\boldsymbol{\%})\end{array}$ \\
\hline Five and below & 22 & 62.86 \\
\hline $6-15$ & 9 & 25.71 \\
\hline $16-25$ & 3 & 8.57 \\
\hline $26-35$ & 1 & 2.86 \\
\hline
\end{tabular}

In terms of the number of years in service as managers, the data revealed that most respondents have served as managers for only five years and below (Table III). It supports the article of Lazzari (2018) that the fastfood industry has exceptionally high turnover rates. It also supports why most of the managers have a relatively low number of years of service.

Table IV. Frequency and percentage distribution on the profile of managers according to the number oftrainings attended

\begin{tabular}{|l|l|l|}
\hline $\begin{array}{l}\text { Number of } \\
\text { Training } \\
\text { Attended }\end{array}$ & $\begin{array}{l}\text { Frequency } \\
(\mathbf{n = 3 5})\end{array}$ & $\begin{array}{l}\text { Percentage } \\
(\mathbf{\%})\end{array}$ \\
\hline 5 and below & 16 & 45.71 \\
\hline $6-10$ & 11 & 31.43 \\
\hline $11-15$ & 5 & 14.29 \\
\hline $16-20$ & 2 & 5.71 \\
\hline 21 and above & 1 & 2.86 \\
\hline
\end{tabular}

The number of trainings attended. It can be gleaned from the data that most of the respondents $(45.71 \%)$ have attended only five and below the training number, which can be considered insufficient (Table IV). 
According to Ukandu and Ukpere (2013), fast food employers rely on workers' skills, knowledge, and abilities to deliver customer services, which makes it essential for employees to be trained and developed to achieve a better work performance. Additionally, a well-trained workforce saves restaurant resources, particularly time and money, and creates higher profitability; hence the managers must receive comprehensive and continuous training to stay outstanding in the highly competitive industry (Carey, n.d.).

Hughes (2020) similarly cited that training and development are necessary notwithstanding what industry the company is into, but it is essential to service-oriented businesses such as the hospitality industry. It is for the reason that it adds value to the experience the employees provide to their customers. Also, ample learning opportunities for the employees is always an investment worth doing.

Hence, it can be deduced that the management must design and offer various capacity enhancement training for continuous improvement of the managerial skills of the restaurant managers since most of the managers had only five and below numbers of training.

Table V. Frequency and percentage distribution on the profile of managers according to their average monthly income

\begin{tabular}{|l|l|l|}
\hline Average Monthly Income & $\begin{array}{l}\text { Frequency } \\
(\mathbf{n = 3 5})\end{array}$ & $\begin{array}{l}\text { Percentage } \\
(\boldsymbol{\%})\end{array}$ \\
\hline $15,000.00$ and below & 17 & 48.57 \\
\hline $15,001.00-20,000.00$ & 9 & 25.71 \\
\hline $20,001.00-25,000.00$ & 6 & 17.14 \\
\hline $30,001.00$ and above & 3 & 8.57 \\
\hline
\end{tabular}

Average monthly income. The result revealed that most of the respondents, 17 (48.57\%), have an average monthly income of P15,000.00 and below (Table V). It can be attributed to the fact that most of the respondents are young and had served as a manager for five years and below only. This salary range can be considered low for a managerial position in the Philippines. The management must therefore create a more attractive compensation/salary scale for managers commensurable to their qualifications.

Level of Management Skills, Work Values and Job Performance of Fast Food Restaurant Managers as Assessed by Themselves and by their Staff

Table VI. Mean distribution on the level of management skills, work values, and job performance of managers as assessed by themselves

\begin{tabular}{|l|l|l|l|}
\hline Indicators & $\begin{array}{l}\text { Weighted } \\
\text { Mean }\end{array}$ & $\begin{array}{l}\text { Standard } \\
\text { Deviation }\end{array}$ & $\begin{array}{l}\text { Verbal } \\
\text { Description }\end{array}$ \\
\hline $\begin{array}{l}\text { Management } \\
\text { Skills }\end{array}$ & 4.52 & 0.65 & Excellent \\
\hline Work Values & 4.62 & 0.58 & Excellent \\
\hline $\begin{array}{l}\text { Job } \\
\text { Performance }\end{array}$ & 4.55 & 0.57 & Excellent \\
\hline
\end{tabular}

Table VII. Mean distribution on the level of management skills, work values, and job performance of managers as assessed by their staff

\begin{tabular}{|l|l|l|l|}
\hline Indicators & $\begin{array}{l}\text { Weighted } \\
\text { Mean }\end{array}$ & $\begin{array}{l}\text { Standard } \\
\text { Deviation }\end{array}$ & $\begin{array}{l}\text { Verbal } \\
\text { Description }\end{array}$ \\
\hline $\begin{array}{l}\text { Management } \\
\text { Skills }\end{array}$ & 4.48 & 0.6583 & Excellent \\
\hline Work Values & 4.52 & 0.6718 & Excellent \\
\hline $\begin{array}{l}\text { Job } \\
\text { Performance }\end{array}$ & 4.51 & 0.6699 & Excellent \\
\hline
\end{tabular}

Tables VI and VII show that managers are excellent in management skills, work values, and job performance as assessed by themselves with an overall mean of 4.52, 4.62, and 4.55, respectively. It is also assessed by their staff with an average mean of 4.48, 4.52, and 4.51. Though the results were interpreted as excellent, still monitoring performance and various capacity enhancement programs are essential for continuous improvement of their managerial performance. 
Spearman's Correlation Coefficient Test of Significant relationship Between the Profile of the Managers and their Management Skills, Work Values, and Job Performance

Table VIII. Correlation analysis of average monthly income of the managers and their management skills

\begin{tabular}{|l|l|l|l|}
\hline Indicators & $\begin{array}{l}\text { Correlation } \\
\text { Coefficient }\end{array}$ & P-Value & Remarks \\
\hline $\begin{array}{l}\text { Management } \\
\text { Skills }\end{array}$ & $0.376^{*}$ & 0.0261 & $\begin{array}{l}\text { Highly } \\
\text { Significant }\end{array}$ \\
\hline
\end{tabular}

The correlation analysis indicates that there is a significant relationship between the income and management skills of the fast-food restaurant managers with a coefficient of .376 (P-value > 0.0261) (Table VIII).

Spearman's Correlation Coefficient Test of Significant relationship Between the Profile of the Managers and their Management Skills, Work Values, and Job Performance

Table IX. Correlation analysis of the average monthly income of the managers and their work values

\begin{tabular}{|l|l|l|l|}
\hline Indicators & $\begin{array}{l}\text { Correlation } \\
\text { Coefficient }\end{array}$ & $\begin{array}{l}\text { P- } \\
\text { Value }\end{array}$ & Remarks \\
\hline $\begin{array}{l}\text { Work } \\
\text { Values }\end{array}$ & $0.339^{*}$ & 0.0464 & Significant \\
\hline
\end{tabular}

Table IX illustrates a significant relationship between the income and work values of the fast-food restaurant managers with a coefficient .339 (P-value > 0.0261).

Spearman's Correlation Coefficient Test of Significant relationship Between the Profile of the Managers and their Management Skills, Work Values, and Job Performance

Table X. Correlation analysis of the average monthly income of the managers and their job performance

\begin{tabular}{|l|l|l|l|}
\hline Indicators & $\begin{array}{l}\text { Correlation } \\
\text { Coefficient }\end{array}$ & $\begin{array}{l}\text { P- } \\
\text { Value }\end{array}$ & Remarks \\
\hline $\begin{array}{l}\text { Job } \\
\text { Performance }\end{array}$ & $0.384^{*}$ & 0.0226 & $\begin{array}{l}\text { Highly } \\
\text { Significant }\end{array}$ \\
\hline
\end{tabular}

It can be gleaned from table $\mathrm{X}$ that there is a high significant relationship between the fast-food restaurant managers' income and job performance with a coefficient of .384 (P-value > 0.0261).

Generally, among the profile variables considered, only the average monthly income was found to have a significant relationship with the managers' management skills, work values, and job performance (Table 8-10).

Boitnott (2018) divulged that by paying employees above-average salaries essentially mean expecting an average work. Pay and benefits may not often be the key motivator for employees. They help, and the reality is that the higher the salaries are likely to incentivize high output culture.

Chron.com (2020) cited that people are often motivated by money. The salary of a worker from his employer can significantly influence his performance in the administration.

These essentially suggest that income plays a crucial role in exhibiting management skills, work values, and the fast-food restaurant managers' job performance.

The following hypotheses were developed:

$\mathrm{H}_{1}$ : There is a positive correlation between income and management skills.

$\mathrm{H}_{2}$ : There is a positive correlation between income and work values.

$\mathrm{H}_{3}$ : There is a positive correlation between income and job performance.

Pearson's r Test of Significant Relationship Between Job Performance of the Managers and their Management Skills

Table XI. Correlation analysis of job performance of the managers and their management skills

\begin{tabular}{|l|l|l|l|}
\hline Indicators & $\begin{array}{l}\text { Correlation } \\
\text { Coefficient }\end{array}$ & P-Value & Remarks \\
\hline $\begin{array}{l}\text { Management } \\
\text { Skills }\end{array}$ & 0.8580 & $4.64 \mathrm{E}-11$ & $\begin{array}{l}\text { Highly } \\
\text { Significant }\end{array}$ \\
\hline
\end{tabular}


The result revealed that management skills are highly significant with job performance with a coefficient of .858 (P-value $>0.05$ ), which leads to the rejection of the null hypothesis (Table XI).

According to Simon (2019), managers in every organization are responsible for implementing and advancing the company's vision and mission. Hence, managers with excellent leadership and management skills are significant in achieving every business organization's goals. Besides, honing these skills and can impact job performance and opportunities (Career Builder, 2020).

Further, Lavoie (2016) cited that strong leaders with good management skills favorably impact a company in various ways, such as reducing turnover, increasing morale, and empowering employees to be more productive. Moreover, the management must lead by example and initiate a positive working environment to perform at their best capacity.On the contrary, weak management skills have long-term adverse effects and may infect the organization's overall operations.

It is ascertained the significant relationship between the management skills and job performance of fast food restaurant managers. It indicates further that the success of the fast-food restaurant lies in the sound and outstanding management and vice versa, and the following hypothesis was developed:

$\mathrm{H}_{4}$ : There is a positive correlation between the fast restaurant managers' management skills and job performance.

Pearson's r Test of Significant Relationship Between Job Performance of the Managers and their Work Values

Table XII. Correlation analysis of job performance of the managers and their work values

\begin{tabular}{|l|l|l|l|}
\hline Indicators & $\begin{array}{l}\text { Correlation } \\
\text { Coefficient }\end{array}$ & P-Value & Remarks \\
\hline Work Values & 0.9200 & $5.95 \mathrm{E}-15$ & $\begin{array}{l}\text { Highly } \\
\text { Significant }\end{array}$ \\
\hline
\end{tabular}

Results revealed that work values are highly significant with job performance with a coefficient of 0.92 (Pvalue>0.05) (Table XII).

Values are essential guiding behavior and enhancing work motivation (Cennamo\&Gardners, 2008). Strong work values play an indispensable role in the workplace. It improves performance (Reddy, 2016). Liao, Lu Huang, and Chiang (2012) likewise inferred that work values influence the employees' job performance.

It implies that work values are positively related to job performance, and the following hypothesis was developed:

$\mathrm{H}_{5}$ : There is a positive correlation between the work values and job performance of fast restaurant managers.

\section{Conclusions}

Fast food restaurant management must therefore consider designing an attractive and competitive compensation scheme commensurable to the position of the fast-food restaurant managers as it is notably related to management skills, work values, and job performance. Conducting an assessment to monitor management skills, work values, and job performance is a worthwhile basis for planning, creating, and implementing managerial capability enhancement programs since both management skills and work values are highly significant to job performance.

\section{References}

Allfoodbusiness.com, "Tips for choosing a restaurant concept," Retrieved from http://www.allfoodbusiness.com/choosing_a_concept.php?no_redirect=true, 2001-2013

N. Bermosa, "The best and most popular Philippine fast food," Retrieved from http://nobertbermosa.blogspot.com/2015/03/the-best -and-most-popular-philippine.htm, March 2015.

J. Boitnott, "7 reasons you should pay your employees an above-average salaries," Retrieved from https://www.inc.com/john-boitnott/7-reasons-you-should-pay-your-employees-above-average-salaries.html, June 2018.

S. Campbell, "Restaurant management tips: What every new manger needs to know," Retrieved from https://wheniwork.com/blog/restaurant-management-

what-every-new-manager-needs-to-know, June 2017.

Campuscrosswalk.org, "Restaurant Industry in the Philippines," Retrieved from https://campuscrosswalk.org/restaurant-industry-in-the-philippines/, n.d. 
G. Cagurangan, "Problems and challenges Encountered by in-premise restaurant managers of Tuguegarao City," Journal of Tourism and Hospitality, 6, 5 Retrieved from https://doi.org/10.4172/2167-0269.1000305, June 2017

J. Carey, “ The importance of training in a restaurant," Retrieved from https://smallbusiness.chron.com/importance-training-restaurant-75676.html, n.d.

Career Builder, "What are management skills and why are they important?" Retrieved from https://www.careerbuilder.com/advice/what-are-management-skills-and-why-are-they-important, July 2020.

D. Celentano, "Three basic casual restaurants formats," Retrieved from https://www.the balancesmb.com/typesof-restaurant-formats-1326193, July 2019.

L. Cennamo and D. Gardner, "Generational differences in work values, outcomes and person-organization values fit,” Journal of Managerial Psychology, vol. 23, no. 5, pp. 8891-906, November 2008

Chron Contributor, "How can salary influence a worker's performance in an administration?, Retrieved from https://work.chron.com/can-salary-influence-workers-performance-administration-25950.htm, July 2020.

Franchise Philippines, "Top 5 Fast Food Restaurant Franchises in the Philippines. Retrieved from https://ifranchise.ph/fast-food-restaurant-franchises/, 2018.

S. Hartzell, "Managerial skills: How good managers promote productivity," Retrieved from https://study.com/academy/lesson/managerial-skills-how-good-managers-promote-productivity.html, June 2012.

J. Hughes, “ The importance of training and development for restaurants," Retrieved from https://www.fsrmagazine.com/expert-takes/importance-training-and-development-restaurants, February 2020.

Industry News, "Quick service remains the best performing restaurant segment, Retrieved from https://www.qmagazine.com./ .../quick-service-remains-best-performing-restaurant-segment, September 2016.

JAP, "Food service Industry in the Philippines," Retrieved from https://www.scribd.com/document/336196674/Food-Service-Industry-in-the- Philippines, 2019.

King World News, "Chronological age vs functional age - How old are you? Retrieved from https://kingworldnews.com/chronological-age-vs-functional-age-how-old-are-you-really/, February 2015.

Z. Lazzari, "The turnover rates in the fast food industry," Retrieved from https://yourbusiness.azcentral.com/turnover-rates-fast-food-industry-25648.html, May 2018.

C. Liao, C. Lu, Huang C. and Chiang, T., "Work values, work attitude and job performance of the green energy industry employees in Taiwan," African Journal of Business Management, vol.6 (15), pp. 5299-5318, April 2012.

J. Lin, P. Shen and Y. Hsu., "Effects of employees' work values and organizational management on corporate performance for Chinese and Taiwanese Construction Enterprises," Retrieved from https://www.researchgate.net/publication/287805075_Effects_of_Employees\%27_Work_Values_and_Organi zational_Management_on_Corporate_Performance_for_Chinese_and_Taiwanese_Construction_Enterprises, December 2015.

P. Loretto, "The top 10 work values employers look for," Retrieved from https://www.thebalancecareers.com/top-work-values-employers-look-for-1986763, November 2019.

A. Lovoie, Here are 4 problems that occur with poor management skills," Retrieved from https://www.entrepreneur.com/article/276919, June 2016.

Mason, Kevin \& Jones, Stephen \& Benefield, Michael \& Walton, "Building consumer relationships in a quick service restaurant industry," Journal of Foodservice Business Research. 19 (4), 368-381. doi:10.1080/15378020.2016.1181508, May 2016.

S. McCombes, "Descriptive research," Retrieved from https://www.scribbr.com/methodology/descriptiveresearch/, May 2019.

Mindtools, "Understanding workplace values: How to find people who fit your organization's culture," Retrieved from https://www.mindtools.com/pages/article/understanding-workplace-values.htm, n.d.

A. Milicevic, "How to manage restaurant staff to get the best from your team," Retrieved from https://possector.com/management/manage-restaurant-staff, n.d.

Pdffiller.com (n.d.), Job performance evaluation form. Retrieved from https://www.pdfiller.com/jsfillerdesk5/?projectld=182165875\&expld=3350\&expBranch=1\#40205611944ab42cd8f76fedc051b8cc3, n.d.

Rancelab.com, "6 Must have tools to manage a Quick Service Restaurant," Retrieved from https://www.rancelab.com/blog/6-tools-manage-quick-service-restaurant/, September 2017.

C. Reddy, "Importance of Work Values. Top 21 Reasons Importance of Work Values. Top 21 Reasons," Retrieved from https://content.wisestep.com/importance-workplace-values-top-reasons/, 2016

J. Rodriguez, "Importance of employee performance in business organization," Retrieved from https://bizfluent.com/about-7601772-importance-employee- performance-business-organizations.html, August 2017.

A. Smuin (2017), “10 leadership skills every manager needs to succeed," Retrieved from https://www.theceomagazine.com/business/10-leadership-skills-every-manager-needs/, 2017. 
K. Simon, "Importance of leadership and management skills for growth of business," Retrieved from https://www.theleadermaker.com/importance-of-leadership-and-management-skills-for-growth-ofbusinesses/, August 2019.

E. Ukandu and W. Ukpere, "Effects of poor training and development on the work performance of the fast food employees in Cape Town. Mediterranean Journal of Social Sciences MCSER Publishing, Rome-Ita. ISSN 2039-9340. Vol 4 No 14. Retrieved from https://www.researchgate.net/ publication /261672501_Effects_of_Poor_Trainingand_Development_on_the_Work_Performance_of_the_Fast_Food_E mployees_in_Cape_Town, November 2013.

V. Wildes, "Should I stay or Should I go? Motivation to work in food service. Journal of Foodservice Business Research, 11:3, 286-294, DOI: $\quad 10.1080 / 15378020802316794$, Retrieved from https://doi.org/10.1080/15378020802316794, October 2008. .

\section{Authors Profile}

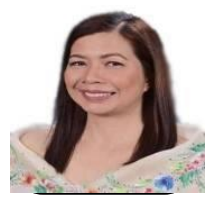

Jessie Anne T. Demetillois a graduate of Doctor of Philosophy in Business Management at Philippine Christian University, Philippines. She has been engaged in conducting and writing researches related to her field and currently designated as a research services coordinator of Cavite State University - TreceMartires City Campus to where she also works as a professor for more than 10 years now. She is also affiliated with several professional organizations and had presented researches in local and international conferences.

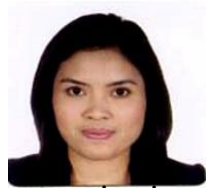

Rosario B. Gumbanis a graduate of Doctor of Philosophy in Business Management at Philippine Christian University. She has been into writing and mentoring researches and presented in local and international conferences. She is a professor in Business Management and Graduate School Open Learning College at Cavite State University. She is also affiliated with numerous professional organizations - national and international.

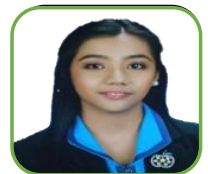

Liane Vina G. Ocampo is a graduate of Doctor of Philosophy in business management at Philippine Christian University. She is a professor in statistics, business and economics at Cavite State University open University College. She had international publication in a peer-reviewed journal in the field of econometrics and presented several research journals in local and international conferences. She is also affiliated with several academic and professional organizations 